\title{
Morphological Characterization of Okra [Abelmoschus esculentus (L.) Moench]
}

\author{
Samiullah Samim*, Sonia Sood, Akhilesh Singh, Anuradha Verma and Amandeep Kaur
}

Department of Vegetable Science and Floriculture CSK Himachal Pradesh Krishi Vishvavidyalaya, Palampur (HP)-176 062, India

*Corresponding author

\begin{abstract}
A B S T R A C T
Keywords

Abelmoschus esculentus

(L.) Moench, Okra,

Colour, Descriptor and

fruit

Article Info

Accepted:

15 September 2018

Available Online:

10 October 2018

Morphological characterization of okra [Abelmoschus esculentus (L.) Moench] germplasm is a prerequisite in any crop improvement programme. 19 accessions of okra collected from different parts of India and Japan were evaluated in 2016 at Chaudhary Sarwan Kumar Himachal Pradesh Krishi Vishvavidyalaya Palampur H.P. for various morphological traits like immature fruit colour, fruit pubescence, ridges per fruit and plant height at the time of horticultural maturity. Among the evaluated genotypes, 2 and 12 had dark green and green fruit colour, respectively.16 had downy fruit pubescence, 17 with five ridges per fruit, 15 genotypes with plant height of $151-250 \mathrm{~cm}$ and four genotypes with $101-150 \mathrm{~cm}$. Green colored fruits were prominent. 14, 2, 2 and 1 genotypes were categorized under green group, yellowish green group, dark green group and dark red group, respectively. 9801, Palam Komal, Hisar Unnat, Parbhani Kranti, VRO-6 and VRO4 were the genotypes which had potential for exploitation in future breeding programme.
\end{abstract}

\section{Introduction}

Okra [Abelmoschus esculentus (L.) Moench] is a warm-season annual herbaceous vegetable crop which can be found in nearly every market in India. The crop, which is generally self-pollinated (Martin, 1983), belongs to the Malvaceae (mallow) family and has its origin in West Africa (Joshi et al., 1974). Tender immature fruits are used in a variety of ways as cooked vegetable, boiled or fried, soups, sauces, stews in meat, frozen, canned and dehydrated products. It is also used in thickening of soups and gravies because of its high mucilage content. Its ripe seeds can be dried, roasted and ground to be used as a coffee substitute (Gemede et al., 2015). The oil from its seeds is utilized in perfume industry. The seed of okra are reported to contain between 15 and $26 \%$ protein and over $14 \%$ edible oil content (WARP 1993). The dried fruit shell and stem containing crude fibre are used in paper industry. For a year round consumption sun dried, frozen and sterilized fruits are also important market products. Nutritionally, okra green fruits are rich in vitamins $(\mathrm{C}, \mathrm{A}$ and $\mathrm{B})$ and minerals ( $\mathrm{Ca}, \mathrm{P}, \mathrm{Mg}$ and $\mathrm{Fe}$ ). It also contains iodine and is, therefore, recommended for the treatment of goitre. Mucilage and fibre content present in okra helps in lowering down the glucose level of blood, hence, good for diabetic 
patients. The crop is the fifth most popular vegetable in India. Its production is widespread across all the major regions. About 10-15 t /ha of yield can be obtained under good management (NARP, 1993).

Globally, okra is grown in an area of $11,17,806$ hectares with a production of $87,06,312$ tonnes and 7.8 tonnes/ha productivity (Anonymous, 2016). India ranks first in the world with annual production of $60,03,000$ tonnes produced from $5,07,000$ hectares area with a productivity of 11.8 tonnes/ha (Anonymous, 2017).

In India, okra is found in its fresh state in almost all markets during summer rainy season and in a dehydrated form during the dry season, particularly in Northern North due to its strong commercial value. It is therefore important that plant breeders developed improved varieties of the okra vegetable, which seems to be the last concern in their research programmes for adoption by Indian vegetable farmers and for the export market. Varieties that combine higher yields and early maturity with longer harvest duration and more so resistant to diseases and pests, would be ideal to the okra vegetable industry in India. Improved varieties in terms of immature fruit colour, fruit pubescence and ridges per fruit are very much desired in the Indian okra export market. In addition, a wide variability in germplasm of okra (Oppong-Sekyer et al., 2011) also provides an ample scope for its improvement for horticultural traits. Characterization of crops is a very essential first step in any crop improvement programme (De Vicente et al., 2005). Characterization of genetic resources, therefore refers to the process by which accessions are identified, differentiated or distinguished according to their characters. Moreover, information obtained on genetic relatedness among genetic resources of crop plants is useful, both for breeding and germplasm conservation (Brown et al., 1990) and thus exploit such variation in breeding programmes to develop improved, high yielding varieties. Accordingly the crop breeding programmes have been designed to suffice the requirements of consumers as well as okra breeders. Morphological descriptors are the base for characterization of plant genotypes on the basis of external appearance. Further characterization of okra varieties is required for their description under plant variety protection legislation, because varietal testing for distinctness, uniformity and stability is the basis for protection for a new plant variety under Indian law (Protection of Plant Varieties and Farmer's right Act, 2011). Proposed new varieties are compared against a set of relevant characteristics prescribed according to (Shrivastava et al., 2001). This investigation was undertaken to study okra genotypes on the basis of morphological traits to select the most promising germplasm for cultivation and use in improvement programs.

\section{Materials and Methods}

The present investigation was carried out under natural field conditions at the Vegetable Experimental Farm of CSK Himachal Pradesh Krishi Vishvavidyalaya, Palampur (HP) during summer-rainy season, 2016.

\section{Experimental site}

\section{Location}

The experimental site is located at an altitude of about $1290.8 \mathrm{~m}$ amsl. Geographic position of the experimental site lies between $32^{\circ} 6^{\prime} \mathrm{N}$ latitude and $76^{\circ} 3$ ' E longitude under mid hill zone of Himachal Pradesh, India.

\section{Climate}

The climate is humid sub-temperate. The mean monthly minimum and maximum temperature varied between 11.5 to 19.5 and 
24.6 to $31.6{ }^{\circ} \mathrm{C}$, respectively during the cropping season. The experimental site experienced average rainfall of $250 \mathrm{~cm}$ annually, out of which about $80 \%$ is received during monsoon period. Monsoon arrives in the second fortnight of June and ends in September. The summer is mild and winter is very severe. The mean weekly meteorological data during the crop growing period of location is given in Fig. 1.

\section{Soil}

The soil of the experimental block was acidic with $\mathrm{pH}$ ranging from 5.0 to 5.6 and soil texture is silty clay to silty loam.

\section{Experimental materials}

The experimental materials comprised of 19 genotypes collected from different parts of India including P-8 and Palam Komal as standard checks (Table 1).

\section{Experimental design and layout plan}

The trial was laid out on May 28, 2016 comprising of 19genotypes, Randomized Complete Block Design (RCBD) with three replications in plot size of $2.7 \mathrm{~m} \times 1.8 \mathrm{~m}$. The genotypes were spaced at $45 \mathrm{~cm}$ between row to row and $15 \mathrm{~cm}$ plant to plant. The experimental field was prepared by ploughing twice with power tiller upto a depth of $20 \mathrm{~cm}$ followed by levelling. Raised beds were constructed at the time of soil preparation to facilitate drainage during the rainy season. The farm yard manure (10 t/ha) was mixed in the soil at the time of field preparation with first ploughing. The chemical fertilizer (100 $\mathrm{kg} \mathrm{N}, 50 \mathrm{~kg} \mathrm{P}_{2} \mathrm{O}_{5}$ and $50 \mathrm{~kg} \mathrm{~K} \mathrm{~K}_{2} \mathrm{O} / \mathrm{ha}$ ) were applied as basal dose at the time of final field preparation. One third of $\mathrm{N}$, full dose of $\mathrm{P}_{2} \mathrm{O}_{5}$ and $\mathrm{K}_{2} \mathrm{O}$ is applied at the time of final field preparation. Remaining two third of $\mathrm{N}$ was top dressed in two equal amounts and added after
30 and 45 days of sowing respectively. The genotypes were evaluated for the immature fruit colour, fruit pubescence and ridges per fruits according to the descriptors for okra (Srivastava et al., 2001); colour of the fruits observed visually and classified into green, dark green and dark red categories. Observations were recorded on 10 randomly chosen plants in each replication at stages of crop growth when the character under study was fully expressed. Fruit colour, fruit pubescence, ridges per plant and plant height were observed at horticultural maturity. The genotypes were characterized and frequency distribution of each descriptor was determined.

\section{Results and Discussion}

There was considerable variation observed among genotypes for all attributes (Table 2 and 3; Plate 1 and 2). Immature fruit colour, fruit pubescence and ridges per fruit are important characters that attract consumers. Immature fruits of four colour intensities were observed. These are grouped as dark green, green, yellowish green and dark red. The genotypes 9801, VRO-4, Parbhani Kranti, P-8, Hisar Unnat, Tulsi-1, SKBS-11, P-20, Parmil1, P-21, Pusa A-4, Japan 5 Ridged, Japan Round and Japan Thick produced green fruits, whereas the entries Palam Komal and VRO-6 produced dark green fruits. Other entries produced yellowish green fruits except Japan Red which produced fruits with dark red colour. Two fruit pubescence viz., downy and slightly rough were recorded. The genotypes Palam Komal, 9801, VRO-4, Parbhani Kranti, P-8, Hisar Unnat, Tulsi-1, VRO-6, P-20, P-21, Pusa A-4, Japan Red, Japan 5 Ridged, Japan Round, Japan Thick and Kanpur Local produced fruits with downy pubescence, while, rest of the genotypes SKBS-11, Parmil1 and IC-169468 produced fruits with slightly rough pubescence. Attractive dark green fruit colour, 5 ridges per fruit and smooth fruit 
surface were the desirable horticultural attributes from consumer's point of view. Fruit colour, fruit pubescence and ridges per fruit and smooth fruit surface are the most important quality factors on the basis of which consumer prefer and these observations often provide preconceived idea about other quality attributes. Barring 9801, VRO-4, Parbhani Kranti, P-8, Hisar Unnat, Tulsi-1, SKBS-11, P-20, Parmil-1, P-21, Pusa A-4, Japan 5 Ridged, Japan Round and Japan Thick produced green fruits, and Palam Komal and VRO-6 all other progenies had green to dark green fruit colour at immature fruit stage. Variation was observed for fruit ridges. Most of the genotypes had 5 ridges perfruit except Japan Round (no ridges) and Japan Thick (8 ridges). The colour of immature fruit varied between dark green, green, yellowish green and dark red. Fruits of all genotypes showed downy to slightly rough pubescence. Fruits of genotypes viz., Palam Komal and VRO-6 were dark green in colour and had downy pubescence. All the genotypes had 5 ridges per fruit except Japan Round and Japan Thick (Table 2). Similar results have been reported by (Chandra et al., 2014; Sawant et al., 2014; Khajuria et al., 2015; Bagwale et al., 2016; Patil et al., 2016; Badiger et al., 2017 and Thulasiram et al., 2017). From above information, it is clear that there exists a considerable scope in the parent material studied for identifying desirable genotypes since significant differences were observed among the genotypes for all the traits studied. Sufficient genetic variability for many of the traits studied had also been reported by earlier workers (Singh et al., 2007; Bendale et al., 2008; Yadav et al., 2010; Ramanjinappa et al., 2011; Reddy et al., 2012; Olayiwola et al., 2014; Mallesh et al., 2015; Chandramouli et al., 2016; Badiger et al., 2017). (Kalia and Padda, 1962; Abdelmageed, 2010) provided information on genetic control of fruit attributes, leaf characters and plant habit in okra.

Table.1 List of okra genotypes and their sources

\begin{tabular}{|l|l|l|}
\hline Sr. No. & Genotype & \\
\hline 1 & Palam Komal & CSK Himachal Pradesh Krishi Vishvavidyalaya, Palampur \\
\hline $\mathbf{2}$ & 9801 & CSK Himachal Pradesh Krishi Vishvavidyalaya, Palampur \\
\hline $\mathbf{3}$ & VRO-4 & Indian Institute of Vegetable Research, Varanasi \\
\hline $\mathbf{4}$ & Parbhani Kranti & Marathwada Agricultural University, Parbhani \\
\hline $\mathbf{5}$ & P-8 & Punjab Agricultural University, Ludhiana, Punjab \\
\hline $\mathbf{6}$ & Hisar Unnat & CCS Haryana Agricultural University, Hissar, Haryana \\
\hline $\mathbf{7}$ & Tulsi-1 & CSK Himachal Pradesh Krishi Vishvavidyala, Palampur \\
\hline $\mathbf{8}$ & SKBS-11 & SK University of Agricultural Sciences and Technology, Srinagar \\
\hline $\mathbf{9}$ & VRO-6 & Indian Institute of Vegetable Research, Varanasi \\
\hline 10 & P-20 & CSK Himachal Pradesh Krishi Vishvavidyala, Palampur \\
\hline $\mathbf{1 1}$ & Parmil-1 & CSK Himachal Pradesh Krishi Vishvavidyala, Palampur \\
\hline $\mathbf{1 2}$ & IC-169468 & NBPGR, Regional Station, Dr. PDKV Campus, Akola, Maharashtra \\
\hline $\mathbf{1 3}$ & P-21 & CSK Himachal Pradesh Krishi Vishvavidyalaya, Palampur \\
\hline 14 & Pusa A-4 & Indian Agricultural Research Institute, New Delhi \\
\hline $\mathbf{1 5}$ & Japan Red & Japan \\
\hline 16 & Japan 5-Ridged & Japan \\
\hline 17 & Japan Round & Japan \\
\hline 18 & Japan Thick & Japan \\
\hline 19 & Kanpur Local & Local area, Kanpur \\
\hline
\end{tabular}


Table.2 Description of okra genotypes based on morphological traits

\begin{tabular}{|c|c|c|c|c|}
\hline Genotypes & $\begin{array}{c}\text { Immature fruit } \\
\text { colour }\end{array}$ & $\begin{array}{c}\text { Fruit } \\
\text { pubescence }\end{array}$ & Ridges per fruit & $\begin{array}{l}\text { Average plant } \\
\text { height }\end{array}$ \\
\hline Palam Komal & 3 & 3 & 2 & $3(209.07)$ \\
\hline 9801 & 2 & 3 & 2 & $2(145.53)$ \\
\hline VRO-4 & 2 & 3 & 2 & $3(170.87)$ \\
\hline Prabhani Kranti & 2 & 3 & 2 & $3(207.24)$ \\
\hline P-8 & 2 & 3 & 2 & $3(214.85)$ \\
\hline Hisar Unnat & 2 & 3 & 2 & $3(224.64)$ \\
\hline Tulsi-1 & 2 & 3 & 2 & $3(154.07)$ \\
\hline SKBS-11 & 2 & 5 & 2 & $3(241.70)$ \\
\hline VRO-6 & 3 & 3 & 2 & $3(196.53)$ \\
\hline P-20 & 2 & 3 & 2 & $3(160.07)$ \\
\hline Parmil-1 & 2 & 5 & 2 & $2(145.60)$ \\
\hline IC-169468 & 1 & 5 & 2 & $3(173.40)$ \\
\hline P-21 & 2 & 3 & 2 & $3(158.73)$ \\
\hline Pusa A-4 & 2 & 3 & 2 & $2(137.80)$ \\
\hline Japan Red & 5 & 3 & 2 & $3(179.46)$ \\
\hline Japan 5-Ridged & 2 & 3 & 2 & $2(110.80)$ \\
\hline Japan Round & 2 & 3 & 1 & $3(174.13)$ \\
\hline Japan Thick & 2 & 3 & 3 & $3(168.87)$ \\
\hline Kanpur Local & 1 & 3 & 2 & $3(164.00)$ \\
\hline
\end{tabular}

Values in parentheses are averages;

Immature fruit colour: $1=$ yellowish green, $2=$ green, $3=$ dark green and $5=$ dark red Fruit pubescence: $3=$ downy, $5=$ slightly rough

Ridges per fruit: $1=$ No ridges, $2=5-7$ ridges per fruit, and $3=8-10$ ridges per fruit Average plant height; $1=<100 \mathrm{~cm} ; 2=101-150 \mathrm{~cm} ; 3=151-250 \mathrm{~cm}$ 
Table.3 Frequency distribution and example genotypes of some attributes of 19 genotypes of okra

\begin{tabular}{|c|c|c|c|c|}
\hline $\begin{array}{l}\text { S./ } \\
\text { No. }\end{array}$ & $\begin{array}{l}\text { Plant } \\
\text { descriptor }\end{array}$ & $\begin{array}{l}\text { Range of } \\
\text { Expression }\end{array}$ & $\begin{array}{l}\text { Number of } \\
\text { genotypes }\end{array}$ & Genotypes \\
\hline 1 & $\begin{array}{l}\text { Immature } \\
\text { fruit colour }\end{array}$ & $\begin{array}{l}\text { Green } \\
\text { Dark green } \\
\text { Yellowish } \\
\text { green } \\
\text { Dark red }\end{array}$ & 2 & $\begin{array}{l}\text { 9801, VRO-4, Parbhani Kranti, P-8, Hisar } \\
\text { Unnat, Tulsi-1, SKBS-11, P-20, Parmil-1, P- } \\
\text { 21, Pusa A-4, Japan } 5 \text { Ridged, Japan Round } \\
\text { and Japan } \\
\text { Palam Komal and VRO-6 } \\
\text { IC-169468 and Kanpur Local } \\
\text { Japan Red }\end{array}$ \\
\hline 2 & $\begin{array}{l}\text { Fruit } \\
\text { pubescence }\end{array}$ & $\begin{array}{l}\text { Downy } \\
\text { pubescence }\end{array}$ & 16 & $\begin{array}{l}\text { Palam Komal, 9801, VRO-4, Parbhani } \\
\text { Kranti, P-8, Hisar Unnat, Tulsi-1, VRO-6, P- } \\
\text { 20, P-21, Pusa A-4, Japan Red, Japan } 5 \\
\text { Ridged, Japan Round, Japan Thick and } \\
\text { Kanpur Local. } \\
\text { SKBS-11, Parmil-1 and IC-169468. }\end{array}$ \\
\hline 3 & $\begin{array}{l}\text { Ridges per } \\
\text { fruit }\end{array}$ & 5-7 Ridges & 17 & $\begin{array}{l}\text { Palam Komal, 9801, VRO-4, Parbhani } \\
\text { Kranti, P-8, Hisar Unnat, Tulsi-1, SKBS-11, } \\
\text { VRO-6, P-20, Parmil-1, IC-169468, P-21, } \\
\text { Pusa A-4, Japan Red, Japan 5 Ridged and } \\
\text { Kanpur Local. }\end{array}$ \\
\hline & & $\begin{array}{l}\text { 8-10 Ridges } \\
\text { No Ridges }\end{array}$ & $\begin{array}{l}1 \\
1\end{array}$ & $\begin{array}{l}\text { Japan Thick. } \\
\text { Japan Round. }\end{array}$ \\
\hline 4 & $\begin{array}{l}\text { Average } \\
\text { plant } \\
\text { height }\end{array}$ & $\begin{array}{l}154.07-241.70 \\
\mathrm{~cm} \\
110-145 \mathrm{~cm}\end{array}$ & 15 & $\begin{array}{l}\text { Palam Komal, VRO-4, Parbhani Kranti, P-8, } \\
\text { Hisar Unnat, Tulsi-1, SKBS-11, VRO-6, P- } \\
\text { 20, IC-169468, P-21, Japan Red, Japan } \\
\text { Round, Japan Thick and Kanpur Local. } \\
\text { 9801, Parmil-1, Pusa A-4, Japan } 5 \text { Ridged. }\end{array}$ \\
\hline
\end{tabular}


Attractive fruit colour, smooth fruit texture and disease free fruits are the desirable attributes from consumer's point of view. Fruit colour and fruit texture are the most important quality factors on the basis of which the consumers prefer dark green/green colored and smooth textured fruits, and these observations often provide preconceived idea about other quality attributes. Barring IC169468 and Kanpur Local, all genotypes had green or dark green or dark red colour at immature fruit stage. The genotypes Palam Komal, 9801, VRO-4, Parbhani Kranti, P-8, Hisar Unnat, Tulsi-1, VRO-6, P-20, P-21, Pusa A-4, Japan Red, Japan 5-Ridged, Japan Round, Japan Thick and Kanpur Local had downy pubescence while rest of them had slightly rough pubescence. The variation in fruit colour, pubescence and ridges per fruit is a varietal character. Dark green colour of fruits coupled with smooth texture is the most desirable trait in lady's finger. Among the highest yielding genotypes 9801 and Palam Komal possessed good quality attributes with green and dark green fruit colour, downy pubescence and 5 ridges. Salameh and Kasrawi (2007), AdeOluwa and Kehinde (2011) reported variability $12 \%$ to $81.2 \%$ and $7.1 \%$, respectively for ridges per fruit in okra.

Sufficient variability existed in the material, which could be exploited through either selection or hybridization. For quality trait i.e. dry matter, Palam Komal, VRO-4 and Parbhani Kranti genotypes can be further put to direct use as cultivars or involved in breeding programmes. Fruits of the genotypes Palam Komal and VRO-6 were dark green, have downy pubescence with five ridges per fruit, which are desirable traits for fresh market. Palam Komal, VRO-4 and Parbhani Kranti were the only genotypeswith all desirable horticultural attributes i.e. Dark green colour, 5 ridges per fruit and smooth fruit surface. Whereas performance of 9801, Palam Komal, Hisar Unnat, Parbhani Kranti,
VRO-6 and VRO-4 were found to be the most promising for fruit yield and other quantitative and quality traits.These genotypes can be used for their exploitation in further breeding programme.

\section{Authors' Contributions}

Samiullah Samim- Conducted the studies and recorded the data in year 2016 at CSKHPKV Palampur HP India. Sonia Sood- Guided and helped to conduct the studies in a proper and scientific manner. Akhilesh Singh- Assisted in writing, compiling and checking the article. Anuradha Sharma- Assisted in writing, compiling and checking the article. Amandeep Kaur- Assisted in writing, compiling and checking the article.

\section{References}

Abdelmageed, A.H.A. 2010. Mode of inheritance of pod spininess in okra (Abelmoschus esculentus (L.) Moench). Trop. and Subtr. Agroecosyst.12: 405409.

AdeOluwa, O.O., and Kehinde, O.B. 2011. Genetic variability studies in West African Okra (Abelmoschus caillei). Agric and Biol. J. of North America2: 1326-1335.

Anonymous. 2017. Handbook of Indian Horticulture Database. National Horticulture Board, Gurgaon, India.

Badiger, M., Pitchaimuthu, M., and Pujer P. 2017. Genetic variability, heritability, genetic advance and correlation studies among quantitative traits in okra (Abelmoschus esculentus (L.) Moench). Glob. J. of Bio-science and Biotech.6: 314-319.

Bagwale, S.B., Jawale, L.N., Deosarkar, D.B., and Jadhav R.A. 2016. Genetic variability studies for yield, yield contributing and quality traits in okra (Abelmoschus esculentus (L.) Moench). 
Indian J. of Agric. Research 50: 614618.

Bendale, V.W., Kadam, R.S., Bhave, S.G., Sawant, S.S., and Desai S.S. 2008. Evaluation of genetic divergence in okra. J. of Maharashtra Agric. Universities33: 91-93.

Brown, A.H.D., Marshall, R., Frankel, O.H., and Williams J.T. 1990. The use ofplant genetic resources. Cambridge University Press, London.

Chandra, S., Bhardwaj, M.L., Kumar, R., Kumar, D., Kumar, S., Gautam, N., Dogra. B., and Sharma S. 2014. Estimation of parameters of variability for different quantitative traits in okra (Abelmoschus esculentus (L.) Moench). Int. J. of Farm Sci. 4: 33-41.

Chandramouli, B., Shrihari, D., Rao, A.V. D. D., and Rao M.P. 2016. Studies on genetic variability, heritability and genetic advance in okra (Abelmoschus esculentus (L.) Moench) genotypes. Pl. Arch.16: 679-682.

De Vicente, M.C., Guzmán, F.A., Engels, J., Ramanatha Rao, V. 2005. Genetic characterization and its use in decision making for the conservation of crop germplasm: The Role of Biotechnology, Villa Gualino, Turin, Italy - 5-7, p 63.

Gemede, H.F., Ratta, N., Haki, G.D., Ashagrie, Z., Woldegiorgis and Beyene F. 2015. Nutritional quality and health benefits of okra (Abelmoschus esculentus): A review. Int. J. of Nutrit. and Food Sci. 4: 208-215.

Joshi, A.B., Gadwal, V.R., and Hardas M.W. 1974. Okra. Abelmoschus esculentus (Malvaceae), In Hutchinson, J., B. (ed.). EvolutionaryStudies in World Crops: Diversity and change in the Indian subcontinent. Cambridge, pp 99-105.

Kalia, M.R., and Padda D.S. 1962. Inheritance of some fruit characters in okra. Indian J. of Genet. and Pl. Breed.22: 248-251.
Khajuria, R.K., Sharma, J. P., Samnotra, R. K., Kumar, S., and Ranjit K. 2015. Variability studies in okra (Abelmoschus esculentus (L.) Moench). Electr. J. of Pl. Breed.7: 0975-928.

NARP. 1993. National Agricultural Research Project, Horticultural crops. Vol. 3, July 1993. NARP, CSIR, Accra.

Olayiwola, M.O., Ariyo, O.J., and Ojo D.K. 2014. Evaluation of genetic variability among okra genotypes (Abelmoschus esculentus (L.) Moench). J. of Pl. and Pest Sci.1: 66-73.

Oppong-Sekyere, D., Akromah, R., Nyama, E.Y., Brenya, E., and Yeboah S. 2011. Characterization of okra (Abelmoschus spp. L.) germplasm based on morphological characters in Ghana. $J$. of Pl. Breed. and Crop Sci. 3: 367-378

Patil, B.T., Rode, V.R., Bhalekar, M.N., and Shinde K.G. 2016. Correlation and Path analysis studies in okra (Abelmoschus esculentus (L.) Moench). Veg. Sci.43: 226-229.

Protection of Plant varieties and Farmer's Right Act. 2001. Department of Agriculture \& Cooperation, Ministry of Agriculture, Government of India, Krishi Bhavan, New Delhi.

Ramanjinappa, V., Arunkumar, K.H., Hugar, A., and M.S. Shashibhaskar. 2011. Genetic variability in okra (Abelmoschus esculentus (L.) Moench). Pl. Arch.11: 435-437.

Reddy, M.T., Babu, K. H., Ganesh, M., Reddy, K.C., Begum H., Reddy, B.P., and Narshimulu G. 2012. Genetic variability analysis for the selection of elite genotypes based on pod yield and quality from the germplasm of okra (Abelmoschus esculentus (L.) Moench). J. of Agric. Techn. 8: 639-655.

Royal Horticultural Society Colour Charts. 1804. Royal Horticultural Society, England, Wales and Scotland London. 
Salameh, N.M., and Kasrawi, M.A. 2007. Inheritance of fruit length, diameter and number of fruit ridges in okra (Abelmoschus esculentus L.) landraces of Jordan. Jordan J. of Agric. Sci.3: 4.

Sawant, S.N., Nagre, P.K., and Deshmukh, S.B. 2014. Genetic variability studies in okra (Abelmoschus esculentus (L.) Moench). National Academy of Agric. Sci.32: 3-4.

Singh, A.K., Ahmed, N., Narayan, R., and Chatoo, M.A. 2007. Variability, correlation and path coefficient analysis in okra under Kashmir conditions. Indian J. of Horticult.64: 472-474.
Srivastava, V., Mahajan, R. K., Gangopadhyay. K. K., Singh, M., and Dhillon, B.S. 2001. Minimaldescriptors for agri-horticultural crops-Part II. Vegetable crops. Monnto Publishing House, Inderpuri, New Delhi.

Thulasiram, L.B., Bhople, S.R., Srikanth, M., and Nayak, B.R. 2017. Genetic variability and heritability studies in okra (Abelmoschus esculentus (L.) Moench). Pl. Arch.17: 907-910.

Yadav, M., Chaurasia, P.C., Singh, D.B., and Singh, G.K. 2010. Genetic variability, correlation coefficient and path analysis in okra. Indian J. of Hort. 67: 456-460.

\section{How to cite this article:}

Samiullah Samim, Sonia Sood, Akhilesh Singh, Anuradha Verma and Amandeep Kaur. 2018. Morphological Characterization of Okra [Abelmoschus esculentus (L.) Moench]. Int.J.Curr.Microbiol.App.Sci. 7(10): 2011-2019. doi: https://doi.org/10.20546/ijcmas.2018.710.232 